\title{
A Court Case Analysis Of Administrative Versus Faculty Grading Rights
}

Homer L. Bates, University of North Florida, USA

Bobby E. Waldrup, University of North Florida, USA

\begin{abstract}
Since 1940, when the AAUP formally defined academic freedom (AAUP, 1984), most faculty members believe they have the final authority in assigning course grades to their students. Faculty members may be surprised that several recent court decisions have concluded that college and university administrators have the right to change grades initially assigned by faculty. This manuscript examines faculty members' rights to assign student grades within the context of academic freedom. Several important recent court decisions on student grading and grade changes are summarized and discussed. Based on these decisions, recommendations are made for both faculty and college and university administrators regarding the assignment of student grades and the student grade appeals process.
\end{abstract}

Keywords: Academic Freedom, Grades

\section{INTRODUCTION}

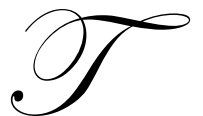

he uncertain role of faculty and administrators in assigning student grades has led to headlines and court cases. The provost of St. Augustine College in North Carolina resigned rather than dismissed a professor who refused to change student grades at the direction of the President (Euben, p. 1, 2001, November 13). In several recent court cases, faculty members have lost suits in which they have complained that administrators have no authority to change grades they have assigned. These court decisions are contrary to the official position of the American Association of University Professors (AAUP). The primary purpose of this manuscript is to examine the current legal landscape regarding a faculty member's rights to assign course grades to students. This examination will explore the concept of academic freedom and will review legal case findings related to academic freedom and grading. Policies and procedures reviewed should aid both faculty and administrators in the grade assignment process.

\section{ACADEMIC FREEDOM}

Academic freedom is the belief that students and faculty have the freedom of inquiry, communication, and teaching ideas or facts without repression, job loss, imprisonment or other negative repercussions. In 1940, the AAUP issued its Statement of Principles on Academic Freedom and Tenure. It identified academic freedom as follows (AAUP, pp. 3-4, 1984):

- $\quad$ Teachers are entitled to full freedom in research and in the publication of the results.

- $\quad$ Teachers are entitled to freedom in the classroom in discussing their subject.

- College and university teachers are citizens, members of a learned profession, and officers of an educational institution. When they speak or write as citizens, they should be free from institutional censorship...(they) should make every effort to indicate that they are not speaking for the institution.

The statements by AAUP have no legal standing; however the AAUP does publicly censure the administrators of colleges and universities who violate their academic freedom standards. At present (November 2009) forty-eight administrators at forty-eight different colleges and universities are under public censure. (AAUP, 2009) 
The AAUP's 1940 Statement did not specifically address the assignment of course grades. However, because of administrative actions and court decisions in the 1980's and early 1990's, the AAUP concluded that a specific statement on faculty grading rights was necessary. In 1998, they issued a document entitled: "The Assignment of Course Grades and Student Appeals.”(AAUP, 2001) This document states: (pp. 1-2)

- The assessment of student academic performance ... including the assignment of particular grades, is a faculty responsibility.

- $\quad \ldots$ (This) is a direct corollary of the instructor's "freedom in the classroom"...

- $\quad$ The faculty member offering the course... should be responsible for the evaluation of student course work and, under normal circumstances, is the sole judge of the grades received by the student in that course.

The AAUP also recommended that grade appeals be heard by faculty members in the department or a closely related field and that grading standards should address whether the faculty member used "appropriate criteria" in determining the grade. (p. 2)

The U.S. Supreme Court has never specifically examined faculty grading rights. It has, however, examined academic freedom. In Sweezy v. New Hampshire (1957), Justice Frankfurter defined the four elements of academic freedom as the freedom of an institution to decide:

- $\quad$ who may attend

- who may teach

- what may be taught

- $\quad$ how it shall be taught

In this decision, academic freedom was recognized as applying to an academic institution, not to individual faculty members or students.

Table 1: Summary of Court Cases

\begin{tabular}{|c|c|c|c|c|c|}
\hline $\begin{array}{l}\text { Case } \\
\text { Name }\end{array}$ & $\begin{array}{l}\text { Parate v. } \\
\text { Isibor }\end{array}$ & $\begin{array}{l}\text { Brown v. } \\
\text { Armenti }\end{array}$ & $\begin{array}{c}\text { Yohn v. Board of Regents } \\
\text { of the University of } \\
\text { Michigan, et al. }\end{array}$ & Benedict College & $\begin{array}{l}\text { Stronach v. } \\
\text { Virginia State } \\
\text { University }\end{array}$ \\
\hline Year & 1989 & 2001 & 2002 & 2004 & 2008 \\
\hline $\begin{array}{l}\text { Rank of } \\
\text { Faculty } \\
\text { Member }\end{array}$ & $\begin{array}{l}\text { Associate } \\
\text { Professor }\end{array}$ & Professor & Associate Professor & $\begin{array}{c}\text { Professor and Associate } \\
\text { Professor }\end{array}$ & Professor \\
\hline $\begin{array}{l}\text { Tenure } \\
\text { Status }\end{array}$ & Untenured & Tenured & Tenured & Both Untenured & Tenured \\
\hline $\begin{array}{l}\text { Academic } \\
\text { Discipline }\end{array}$ & $\begin{array}{c}\text { Civil } \\
\text { Engineering }\end{array}$ & Counseling & Dentistry & $\begin{array}{c}\text { Biology and } \\
\text { Environmental Health }\end{array}$ & Physics \\
\hline $\begin{array}{c}\text { Type of } \\
\text { Institution }\end{array}$ & Public & Public & Public & Private & Public \\
\hline $\begin{array}{l}\text { General } \\
\text { Issue }\end{array}$ & $\begin{array}{l}\text { Faculty } \\
\text { member } \\
\text { refused to } \\
\text { change a } \\
\text { student's } \\
\text { grade from B } \\
\text { to A and his } \\
\text { appointment } \\
\text { was not } \\
\text { renewed. }\end{array}$ & $\begin{array}{l}\text { Faculty } \\
\text { member } \\
\text { refused to } \\
\text { change a } \\
\text { student's } \\
\text { failing grade } \\
\text { and was } \\
\text { terminated. }\end{array}$ & $\begin{array}{l}\text { Faculty member was a } \\
\text { member of a 4-person } \\
\text { faculty panel that failed } \\
\text { two students repeating a } \\
\text { clinical project. Failing } \\
\text { grade was not recorded and } \\
\text { another panel was } \\
\text { constituted that passed the } \\
\text { two students. }\end{array}$ & $\begin{array}{l}\text { Two faculty members } \\
\text { refused to assign grades } \\
\text { partially based on effort } \\
\text { as required by the } \\
\text { college administration. } \\
\text { They were dismissed } \\
\text { for failure to follow the } \\
\text { administrative directive. }\end{array}$ & $\begin{array}{l}\text { Faculty member } \\
\text { refused to change a } \\
\text { student's grade from } \\
\text { D to A. Grade was } \\
\text { changed by the } \\
\text { administration and } \\
\text { faculty member sued } \\
\text { to change grade } \\
\text { back to the original } \\
\text { D. }\end{array}$ \\
\hline
\end{tabular}




\section{COURT CASES}

Important (and interesting) court cases are now examined and discussed. These cases are relatively current dating from 1989 to 2008. The cases selected for examination and discussion are diverse and deal with tenured and nontenured faculty, small and large institutions, public and private institutions, and with faculty from a variety of academic disciplines. They were chosen because of the important issues raised and because of the notoriety that these cases have generated in the academic press. The court cases are summarized in Table 1 with detailed information about case allegations and findings being summarized in the text.

\section{Parate v. Isibor (1989)}

Natthu S. Parate was appointed as an Associate Professor in the Tennessee State University Department of Civil Engineering for the 1982-83 academic year. He was appointed to a tenure-track position which was renewable on an annual basis. Edward I. Isibor was the Dean of the School of Engineering and Technology which housed the Department of Civil Engineering. During his first semester, Parate explained to his students his grading scale and he also stated that he would consider extenuating circumstances when assigning final grades. In one course, after final grades were distributed, two students approached Parate and requested grade changes from B to A. One student argued that he had extenuating circumstances since he was involved in a serious legal matter during the term. Parate agreed to change the letter grade and discussed the matter with the department chair who concurred with Parate. The second student had been observed cheating on the final examination and had offered medical excuses that Parate thought lacked credibility. Parate decided not to change the second student's grade and the department chair concurred with Parate's decision.

The second student met with Dean Isibor to request a grade change; the associate dean met with Parate and after hearing his explanation agreed that there was no reason to change the grade of the second student. Isibor insisted on a meeting between Parate, the Associate Dean, and the Department Chair. At the meeting, Isibor insisted that Parate change the second student's grade which Parate refused. After being threatened with a poor annual evaluation, Parate finally signed a memorandum changing the grade. During the following two academic years, Isibor and the Department Chair retaliated against Parate by sending him a critical letter, giving him low performance evaluations, and refusing requests for professional travel. In March, 1985, upon the recommendation of the Department Chair and Isibor, the President of Tennessee State University sent Parate a nonrenewal letter stating that he would be terminated after the 1985-86 academic year. During the 1985-86 academic year, Parate was continually harassed by Isibor and the Department Chair and they sent faculty observers to his classes.

On April 4, 1986, Parate brought civil action against Isibor for violations of his right to academic freedom under the First Amendment. The $6^{\text {th }}$ Circuit Court held that “...the assignment of a letter grade is symbolic communication intended to send a specific message to the student, the individual professor's communicative act is entitled to some measure of First Amendment protection." The Court also stated that the University administrators could have changed the grade themselves; the unconstitutional act was specifically compelling Parate to change the grade. The only reason that Parate's constitutional rights were violated was because he was compelled to change the grade. If the administration believed that Parate's grading process was not appropriate, the Court argued that they could have administratively changed the student's grade.

\section{Brown v. Armenti (2001)}

Robert A. Brown was a tenured professor at California University of Pennsylvania teaching in the field of education. At the end of the Spring 1994 term he assigned a F grade to one of his students in a graduate clinical education course because she had attended only 3 of 15 classes. The student appealed the grade to the President of the University, Armenti, who ordered Brown to change the grade from F to I - Incomplete. Brown refused to change the grade and was dismissed. President Armenti later justified the dismissal on the grounds of sexual harassment. An arbitrator ordered Brown's reinstatement. 
Brown filed a freedom of speech suit in federal court. Armenti appealed to the U. S. Court of Appeals and a three-judge panel ruled in President Armenti's favor. The $3^{\text {rd }}$ Circuit stated that "...a public university professor does not have a First Amendment right to expression via the school's grade assignment procedures." The court ruled that "...because grading is pedagogic, the assignment of the grade is subsumed under the university's freedom to determine how a course is taught." By its decision, the Court rejected the decision in Parate v. Isibor.

Brown decided not to appeal the court's decision and dropped his lawsuit and retired from the university. His attorney stated that he had grown tired of the fight and of the legal expenses involved in any appeal. (O'Neil, 2001)

Yohn v. Board of Regents of the University of Michigan, et al. (2002)

L. Keith Yohn was a tenured Associate Professor of Dentistry at the University of Michigan. In October 1999 Yohn was chosen as one of four professors to serve on a panel to evaluate the projects of two dental students (one of whom was a daughter of a part-time faculty member) (Chronicle of Higher Education, 2000), enrolled in a required clinical course. Both students were repeating the course having failed it previously. After both students completed their makeup projects consisting of preparing crowns and a temporary bridge on a mannequin, the panel met for over two hours and unanimously agreed that both students had failed the project for the second time which meant a letter grade of $\mathrm{F}$ for the course and possible dismissal from the program. The panel reported their decision to the interim associate dean of the School. The interim associate dean did not record these grades. The panelists were later informed that the two students were allowed to redo the projects for a third time and were evaluated by a different faculty panel. The students redid the projects and the new panel gave them grades of $\mathrm{C}$ and $\mathrm{C}+$. Yohn sued the University of Michigan for changing the grades.

The Court ruled in favor of the Board of Regents. The court stated: "An educator has a First Amendment constitutional right to academic freedom in issuing grades..." “...the assignment of a letter grade is symbolic communication intended to send a specific message to the student (and) is entitled to some measure of First Amendment protection.” The court later stated: “...an educator's First Amendment right...is violated only when the educator himself or herself is compelled to change a student's grade. ...If a grade is changed administratively as opposed to requiring the educator to personally alter the grade marking, then such a situation does not rise to the level of a constitutionally protected First Amendment right, inasmuch as a professor has no constitutional interest in a grade ultimately received by a student...."

\section{Benedict College (2004)}

Benedict College is a small historically black college located in Columbia, South Carolina. Because of decreased enrollments by freshmen and sophomore students, in the spring of 2002, President David H. Swinton initiated his SEE or SE2 (Success Equals Effort) program. Under this program, freshmen and sophomore students were to be graded on a combination of their knowledge (as shown by test scores and other graded work) and effort (as shown by attendance, participation, etc.). For freshmen students, a final grade was to be based $60 \%$ on effort and $40 \%$ on knowledge; for sophomore students, it was 50\% effort and 50\% knowledge. Grades for juniors and seniors were to be based entirely on knowledge. The Benedict College faculty did not approve the SEE program and did not have an opportunity to review it prior to its implementation.

Professors Milwood Motley and Larry Williams were members of the Biology, Chemistry, and Environmental Science Department at Benedict College. Motley taught Biology and Williams taught Environmental Health. Both faculty members were opposed to the SEE program. Motley implemented the program in the spring 2002 semester; however, Williams did not. Neither faculty member adhered to the program subsequently.

At the end of the fall 2003 semester, the university administration realized that many faculty were not adhering to the SEE policy. The Dean of the School of Science, Technology, Engineering, and Mathematics sent a memo to faculty members asking those not adhering to the policy to explain their justification. Both Motley and Williams responded with their reasoning and the dean instructed them to change their fall 2003 grades consistent 
with the SEE policy. They both refused to do so and Motley received a letter dated June 8, 2004, dismissing him on grounds of insubordination. It is unclear whether a similar letter was sent to Williams since he was out of town during the summer 2004. Upon Williams return, a certified termination letter was sent in late August 2004.

Motley appealed his termination to the college's Faculty and Staff Grievance and Appeals Committee. The committee was comprised of seven members with four being faculty and three administrators. The committee voted 4-3 to recommend rescinding the termination. All four faculty members voted together. President Swinton rejected the committee's recommendation. Williams also appealed to the committee and a hearing was held on September 9, 2004. The President had reconstituted the appeals committee by appointing a larger number of administrators and the committee voted 5-2 to sustain the dismissal of Williams. Both Motley and Williams initiated litigation in Richland County, South Carolina, circuit court in 2004. Benedict College reached a confidential settlement with both Motley and Williams in 2007.

Benedict College was censured in 1994 due to deficiencies in college policies governing faculty appointments. The censure remains in effect. The AAUP condemned Benedict College for the actions against Motley and Williams.

\section{Stronach v. Virginia State University (2008)}

Carey E. Stronach was a tenured physics professor at Virginia State University (VSU). During the spring 2006 term, Stronach taught an introductory physics class with the student's final grades being determined by the average of the three highest grades on five quizzes. One particular student received scores of 16, 66, 89, 21 and 22 during the term. The average of the three highest scores resulted in an average score of 59 which corresponded to an F on Stronach's grading scale. However, Stronach awarded the student a course grade of D. The student disagreed with the grade computation believing that he had received scores of 95 on the last two quizzes instead of scores of 21 and 22. The student forwarded Stronach copies of his two examination papers, however, Stronach believed they had been changed and took no actions.

The student met with the Department Chair of Chemistry and Physics, Ralph C. Gatrone, who changed the grade on file to an A. Stronach disagreed and took the disagreement to Larry C. Brown, the Dean of the School of Engineering, Engineering Technology, Industrial Education and Technology, and then to Provost W. Eric Thomas. The Provost agreed with the Chair's actions and left the students grade as an A. Stronach brought suit to have the grade changed back to a D and cited racial discrimination and the constitutionally protected concept of academic freedom.

The Court ruled against Stronach and stated: “...the Court finds no constitutional right to academic freedom exists that would prohibit senior VSU officials from changing a grade given by Stronach to one of his physics students against his will. Even if all of the facts occurred as Stronach has alleged, he has failed to state a claim for which this Court could afford relief."

\section{Policy and Procedure Recommendations}

Donna R. Euben (p. 6, 2001, November 13) lists several suggestions for both administrators and faculty members to avoid legal issues associated with student grading. She lists seven practical suggestions. These are quoted as follows:

- $\quad$ Faculty and administration should develop clear, written grading policies, governing any and all grading standards and appeal procedures.

- $\quad$ Such policies should be widely distributed to students, faculty members, and administrators.

- A grade appeals committee should ordinarily consist of faculty members in the department or in closelyrelated fields.

- $\quad$ Once a grade appeal policy is established, it should be applied in a fair and consistent fashion.

- Every effort should be made to resolve differences about grades, including between faculty and administration, within the university. 
- $\quad$ A grade appeal policy "should . . . be available for reviewing allegations that inappropriate criteria were used in determining the grade or that the instructor did not adhere to stated procedures or grading standards."

- $\quad$ Administrators should avoid unilaterally changing a grade assigned by a faculty member and usurping the faculty prerogative to evaluate students academically.

The primary themes of the recommendations are that faculty, administrators and students should treat each other with respect and that grading and grade appeals policies should be in writing and should be agreed upon by all parties involved. Faculty members would benefit from education about the limits of their First Amendment rights.

\section{CONCLUSIONS}

The court decisions since Parate v. Isitor (1989) are not particularly comforting to faculty members in terms of their rights to assign student grades. The view of the courts appears to be that assigning course grades is not an absolute right of university faculty members. University administrators have the right to change grades based on student appeals. It is clear, however, that administrators may not force faculty members to change student grades. Coercing faculty members to change grades is a violation of their First Amendment rights.

\section{AUTHOR INFORMATION}

Homer L. Bates is a Professor of Accounting in the Coggin College of Business at the University of North Florida. He holds a B.S. and an MBA from Indiana University and a Ph.D. in Accountancy from the University of Illinois. $\mathrm{He}$ is a CPA in Indiana. He has previously published in several journals including the Journal of Accountancy, the CPA Journal, Business Horizons, and the California Management Review.

Bobby E. Waldrup the Associate Dean and Associate Professor of Accounting in the Coggin College of Business at the University of North Florida. He holds a BPA and MPA from Mississippi State University and a Ph.D. in Accountancy from the University of Mississippi. He is certified as a CPA in Mississippi. He has previously published in, among others, the CPA Journal, the Journal of Information Systems, and Strategic Finance.

\section{REFERENCES}

1. American Association of University Professors (AAUP), (1984). 1940 Statement of Principles of Academic Freedom and Tenure with Interpretive Comments, AAUP Policy Documents and Reports, 1940 edition. Washington, DC: American Association of University Professors.

2. American Association of University Professors (AAUP), (2001), The Assignment of Course Grades and Student Appeals, AAUP Policy Documents and Reports, 2001 edition. Washington, DC: American Association of University Professors.

3. American Association of University Professors (AAUP), (2009), Censured Administrators, Washington, DC: American Association of University Professors.

4. $\quad$ Brown v. Armenti, (2001), 247 F.3d 69 (3d Cir. 2001).

5. Euben, D. R. (2001, November 13). Who Grades Students? Some Legal Cases, Some Best Practices. Retrieved September 22, 2009, from University of Michigan, AAUP Chapter

6. O’Neil, Robert (2001), "Free Speech for Professors: 2 Court Rulings Sound New Alarms," The Chronicle of Higher Education, June 1, 2001.

7. $\quad$ Parate v. Isibor, (1989) 868 F.2d 821 (6th Cir. 1989).

8. Stronach v. Virginia State University, (2008) civil action 3:07-CV-646-HEH (E. D. Va. Jan. 15, 2008).

9. $\quad$ Sweezy v. New Hampshire, (1957) 354 U.S. 234, 250 (1957).

10. Yohn v. University of Michigan, et al. (2002) 39 Fed. Appx. 225 (6th Cir. 2002)

11. (2000), "Dentistry Professor Sues U. of Michigan Over Grade Change," The Chronicle of Higher Education, February 11, 2000, p. A16. 